\title{
Program Edukasi Masyarakat Pasca Pandemi COVID-19 Melalui Kreativitas Desain Di Banjar Padangtegal Mekarsari, Desa Ubud, Kabupaten Gianyar
}

\author{
Made Ida Mulyati ${ }^{1}$, Mitariani ${ }^{2}$ \\ ${ }^{1}$ Program Studi Desain Interior Institut Seni Indonesia Denpasar \\ ${ }_{2}^{2}$ Program Studi Desain Fashion Institut Seni Indonesia Denpasar \\ idamulyati@isi-dps.ac.id
}

ISI Denpasar tahun 2020 melaksananakan program KKN dengan tema kegiatan KKN dimasa pandemi COVID-19. Tema tersebut bertujan memberikan pemikiran mengedukasi warga desa melalui desain kreatif yang terkait dengan penanggulangan dan dampak penyebaran COVID-19 . Untuk merealisasikan tujuan tersebut, maka mahasiswa diwajibkan menyusun program KKN yang sesuai untuk membantu masyarakat dalam menanggulangi dan menghadapi dampak pandemi COVID-19 di lingkungan desa tempat tinggal merekmasing-masing. Program edukasi disusun dan direalisasikan oleh mahasiswa disesuaikan dengan bidang keahliannya yaitu desain mode. Program tersebut antara lain memberikan pelatihan pembuatan masker kreatifdan pelatihan pemanfaatan baju yang sudah lama tidak dipakai dengan teknik tie dye. Tujuan program tersebut memberikan edukasi untuk menunjang perekonomian warga masa pandemi COVID-19, khususnya di Banjar Padangtegal Mekarsari, Desa Ubud, Kabupaten Gianyar. Program kerja tersebutdijalankan melalui penayangan video tutorial dan pendampingan langsung dengan tetap memperhatikan protocol kesehatan. Vidio tutorial tersebut nantinya bersinergi dengan jaringan YouTube milik Desa Ubud, sehingga mampu memberikan edukasi sejalan dengan program pengembangan perekonomian desa di masa pandemi COVID-19. Untuk tujuan jangka panjangnya program edukasi tersebut nantinya diharapkan mampu memberikan edukasi lebih luas di kalangan pengguna YouTube. Respon diberikan warga Banjar Padagtegal Mekarsari sangat baik, terbukti cukup banyak warga desa mendukung dan bersedia ikut dalam program edukasi tersebut.

Kata Kunci : ISI Denpasar, KKN, pandemi COVID-19, desain mode, edukasi, kain perca, masker, baju bekas,teknik tie dye, video tutorial, pendampingan, protokol kesehatan, jaringan, you tube, respon, Banjar Padangtegal

ISI Denpasar in 2020 implemented kkn program with the theme of KKN activities during the COVID19 pandemic. The theme is to give the thought of educating villagers through creative design related to the countermeasures and impact of covid-19 spread. To realize this goal, students are required to develop a suitable $\mathrm{KKN}$ program to assist the community in tackling and dealing with the impact of the COVID-19 pandemic in their respective brand-owned villages. Educational programs are organized and realized by students tailored to their area of expertise, namely fashion design. The program includes creative mask making training and long-nosed shirt utilization training with tie dye techniques. The purpose of the program is to provide education to support the economy of residents during the COVID-19 pandemic, especially in Banjar Padangtegal Mekarsari, Ubud Village, Gianyar Regency. The program is run through the delivery of video tutorials and direct mentoring while paying attention to health protocols. Vidio tutorial will synergize with the YouTube network owned by Ubud Village, so that it is able to provide education in line with the village's economic development program during the COVID-19 pandemic. For the long-term purpose, the educational program is expected to provide more education among YouTube users. The response given by banjar padagtegal mekarsari residents is very good, proven that enough villagers support and willing to participate in the educational program 
Keywords : ISI Denpasar, KKN, COVID-19 pandemic, fashion design, education, cloth, mask, used clothes, tie dye technique, video tutorial, mentoring, health protocol, network, you tube,response, Banjar Padangtegal

Proses review: 1 - 4 Mei 2O21, Dinyatakan lolos 5 Mei 2021

\section{PENDAHULUAN}

Institut Seni Indonesia Denpasar tahun 2020 mengangkat tema kegiatan KKN dimasa pandemi COVID-19. Tema tersebut bertujan memberikan sebuah pemikiran untuk mengedukasi masyarakat melalui desain kreatif yang terkait dengan penanggulangan dan dampak penyebaran COVID-19 . Mahasiswa melaksanakan program KKN sebagian dengan daring dan sebagian dilakukan terjun langsung ke lapangan dengan tetap menjalankan protocol kesehatan. Sedangkan sistem pembimbingan oleh dosen pembimbing kepada mahasiswa dilakukan dengan daring. Pembimbingan dilakukan dari tahap penentuan program sampai penulisan laporan akhir KKN. Program yang dibuat oleh mahasiswa harus sesuai dengan bidang keilmuan yang diambil di bangku kuliah. Program yang dibuat oleh mahasiswa diharapkan nantinya mampu memberikan sumbangsih terhadap masyarakat dalam menghadapi pandemi COVID-19.

Dalam menghadapi pandemi COVID-19 sangat besar dampak terhadap masyarakat seperti terganggunya perekonomian masyarakat karena pendapatan masyarakat kabupaten Gianyar sebagian besar tergantung dari pariwisata. Sedangkan pariwisata, kesenian, pendidikan dan kegiatan lainnya derastis menurun disaat pandemi COVID-19. Untuk memutuskan rantai penyebaran COVID-19 dihimbau untuk semua lapisan masyarakat dalam menjalain kegiatan sehari-hari dengan memperhatikan protocol kesehatan seperti menggunakan masker pada saat keluar rumah, disinfektan yang rutin disemprotkan disekitar ruangan dan halaman rumah, hand sanitizer yg digunakan pada tangan sesering mungkin atau melakukan pencucian tangan sesering mungkin, dan pembatasan ruang gerak sosial. Namun masih banyak masyarakat yang belum sadar betapa pentingnya melaksanakan protokol kesehatan tersebut. Untuk itu perlu dilakukan program edukasi yang mampu memberikan penjelasan tentang pentingnya protokol kesehatan untuk bersama-sama dilaksanakan oleh waga desa setempat.
Penggunaan masker merupakan hal yang paling penting di dalam menjalankan protokol kesehatan karena virusakan lebih cepat masuk ke tubuh melalui hidung dan mulut. Tetapi dimasa pandemi COVID-19 perekonomianmasyarakat semakin merosot. Dengan situasi kemerosotan ekonomi terkadang masyarakat golongan lemah untuk membeli masker saja tidak mampu karena harus membeli untuk semua anggota keluarga dan minimal satu orang dua masker. Selain itu untuk dalam masa pandemi COVID-19 ini untuk menghindari virus tersebut selain memperhatikan protokol kesehatan ,factor psikologi (kejiwaan) harus dijaga kenyamanannya. Contoh dari factor psikologi yaitu tetap memiliki rasa gembira, tenang dan bahagia di dalam menghadapi pandemi COVID-19, supaya sitem imun meningkat sehingga akan lebih sulit terkena virus. Untuk memenuhi rasa bahagia salah satunya memenuhi keinginan dengan menggunakan baju yang baru sedangkan dimasa pandemiCOVID-19 perekonomian masyarakat yang menurun, sehingga masyarakat pada umumnya mengutamakan kebutuhan pangan untuk mempertahankan hidup. Tetapi terkadang ada cara agar kita dapat memakai baju yang baru dengan memodifikasi baju yang sudah tidak dipakai yang sebetulnya masih layak dipakai.

Untuk menjawab kebutuhan dan permasalahan di atas, beberapa program kerja yang dilaksanakan mahasiswa dari jurusan desain mode yang bernama Mitariani, Antara lain memberikan edukasi tentang pembuatan masker kreatif dengan memanfaatkan kain perca dengan bantuan mesin jahit dan baju yang sudah tidak dipakaitetapi masih layakuntuk dipakai dimodifikasi dengan teknik tie dye. Program ini bertujuan untuk menumbuhkan kreativitas desain bagi skaa teruna-teruni di Banjar Padangtegal Mekarsari, Desa Ubud, Kabupaten Gianyar. Program ini dibuat sejalan dengan isu tentang melemahnya perekonomian di Kabupaten Gianyar pasca pandemi (Ringtimesbali, 2020). Selain itu program kerja ini merupakan permintaan dari kepala desa agar dapat menumbuhkan kreativitas warga terutama bagi skaa teruna-teruni di Banjar Padangtegal Mekarsai, Desa Ubud, Kabupaten Gianyar untuk mengisi 
kekosongan waktu. Kreativitas desain bagi skaa teruna-teruni diharapkan nantinya dapat membantu meringankan beban ekonomi keluarga. Program kerja tersebut dibuat sesuai dengan bidang keilmuan mahasiswi yaitu desain mode.Tujuan program kerja tersebut adalah memberikan edukasi untuk menunjang perekonomian warga di masa pandemi COVID-19, khususnya di Banjar Padangtegal Mekarsari, Desa Ubud, Kabupaten Gianyar. Program kerja yang dijalankannya melalui penayangan video tutorial mengenai bahan dan alat yang diperlukan di dalam pembuatan baju dengan teknik tie dye dan pembuatan masker kreatif. langkah-langkah bersinergi denganjaringan YouTube milik Desa Ubud, sehingga mampu memberikan edukasi yang sejalan dengan program pengembangan perekonomian desa di masa pandemi COVID-19.

\section{METODE}

Jenis penilitian adalah penelitian lapangan (field research) dan merupakan penelitian kualitatif. Fokus penelitian ini adalah kajian tentang model KKN integratifinterkonektif berbasis pada pengembangan masyarakat yang produktif, inovatif dan kreatif (Muleong, 2000: 29). Penelitian ini termasuk penelitian diskriptif kualitatif (Sukmadinata, 2001: 60- 62). Subyek peneliti atau responden dalam penelitian ini adalah mahasiswa KKN Istitut Seni Indonesia Denpasar, warga di Banjar Padangtegal Mekarsai, Desa Ubud, Kabupaten Gianyar. Populasi dalam penelitian kualitatif dinamakan "social situation" atau situasi sosial yang terdiri atas tiga elemen yaitu: tempat (place), pelaku (actors), dan aktivitas (activity) yang berinteraksi secara sinergis disesuaikan dengan masa pandemi COVID-19. Data yang dikumpulkan bersifat primer dari program yang langsung dilakukan di lapangan seperti memberi pelatihan dan penyuluhan. Wujud data berupa foto pelatihan dan penyuluhan, brosur cara menjalnkan protocolkesehatan dan video di YouTube. Setelah itu data dianalisis dengan menggunakan model Miles dan Huberman dalam (Sugiyono, 2010). Proses analisis data model Miles dan Huberman, meliputi : 1) Reduksi data; 2) Penyajian data; 3) Kesimpulan. Reduksi data meliputi program yang dibatasi pada kegiatan edukasi. Penyajian data berupa deskripsi kegiatan dari data berupa foto dan video. Setelahnya akan ditarik kesimpulan tentang proses pelaksanaan program kerja dan keterlibatan masyarakat dalam program kerja tersebut.

\section{ANALISIS DAN INTERPRETASI DATA}

Sesuai dengan metode di atas, pembahasan dibatasi pada kegiatan edukasi seperti pembuatan video dan sosialisasi terkait program kerja KKN masingmasing peserta. Pembahasan menggunakan kalimat deskriptif sesuai dengan laporan kegiatan per minggu. Berikut ini merupakan pembahasan program kerja yang dilaksanakan mahasiswa di wilayahnya masing-masing.

Pelaksanaan Program Pembuatan Masker Kreatif dan pembuatan Baju dengan Teknik Tie Dye di Desa Padangtegal Ubud Kabupaten Gianyar

\section{Kegiatan Minggu Pertama Bulan Agustus Tahun 2020}

Pada minggu pertama tepatnya dari tanggal 1 sampai 6 Agustus kegiatan mahasiswa dari jurusan desain mode di Banjar Padangtegal Mekarsari, Desa Ubud, Kabupaten Gianyar dimulai dari persiapan dan pembuatan videotutorial tentang pembuatan masker kreatif. Masker yang dibuat menggunakan peralatan benang dan jarum jahit, kain perca yang sangat mudah didapat. Pembuatan masker kreatif di bantu dengan menggunakan mesin jahit. Setelah video tutorial pembuatan masker kreatif selesai nantinya video tutorial disebarkan melalui mediasosial seperti YouTube dan whatsapp ke setiap muda-mudi yang merupakan anggota sekaa teruna- teruni di Desa Padangtegal Ubud Kabupaten Gianyar. Mereka sangat antusias mendapatkan video tutorial cara-cara pembuatan masker kreatif karena dapat menambah ilmu dan dapat dikembangkan sebagai modal usaha kecil untuk membantu menurunnya perekonomian keluarga diakibatkan karena pandemi COVID-19 di masa sekarang ini.
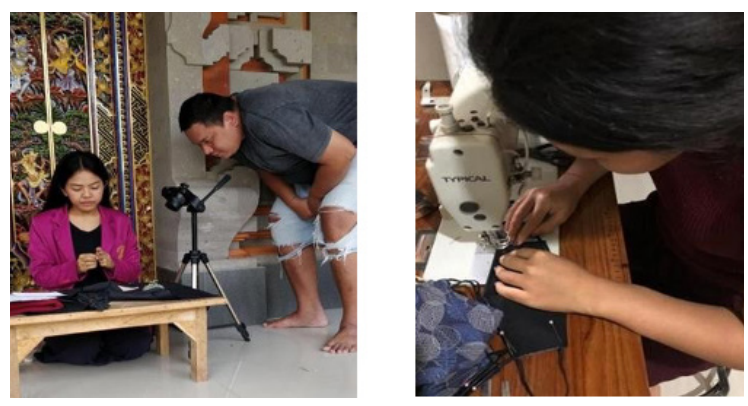

Foto 1. Proses Pengambilan Gambar Video Tutorial Pembuatan Masker(Sumber : Mahasiswa, 2020) 

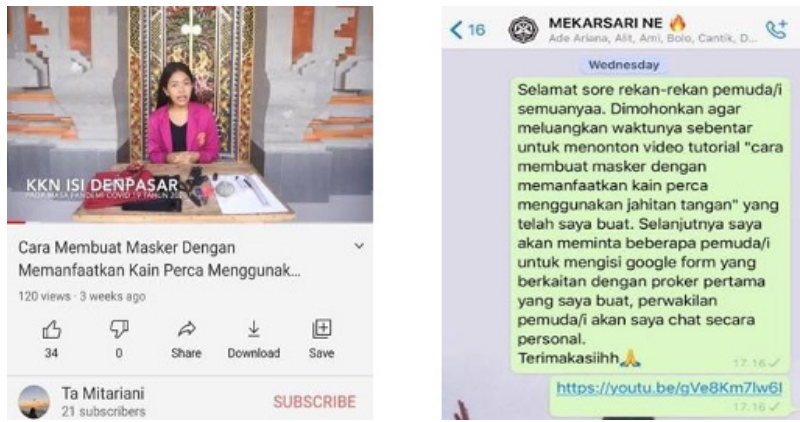

Foto 2. Vidio tutorial cara-cara pembuatan masker kreatif di bagikadi akun YouTube dan whatsapp (Sumber : Mahasiswa, 2020)

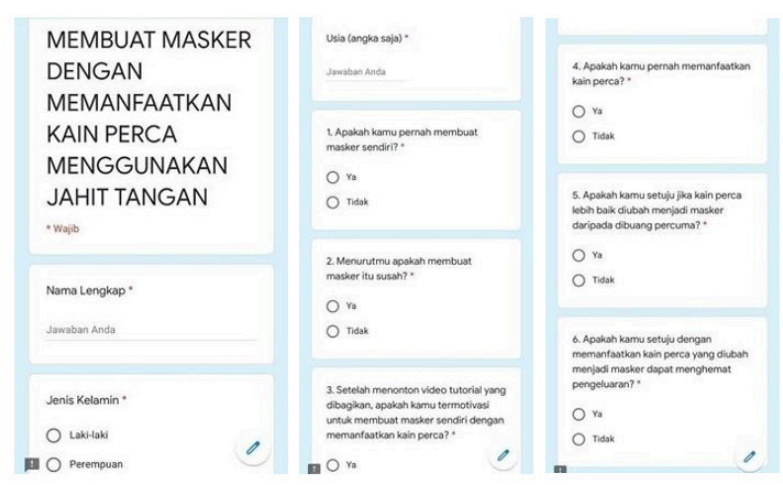

Gambar 2. Memberikan kuesioner kepada 20 orang bagi skaa teruna-teruni di Desa Padangtegal Mekarsari Ubud , Kabupaten Gianyar melalui google formulir

\section{Kegiatan Minggu Kedua Bulan Agustus Tahun 2020}

Pada minggu kedua kegiatan mahasiswa dari jurusan desain mode di Banjar Padangtegal Mekarsari, Desa Ubud, Kabupaten Gianyar dimulai dari persiapan dan pembuatan video tutorial dari persiapan bahan yang akan digunakan dan cara-cara memodifikasi baju yang sudah tidak dipakai tetapi masih layak dipakai denganteknik tie dye. Kemudian dilanjutkan dengan pengeditan video oleh mahasiswa. Setelah itu video tutorial dibagikan di akun YouTube pribadi penulis. Setelah itu link video dibagikan ke grup whatsapp Skaa teruna-teruni di Banjar Padangtegal Mekarsari, Desa Ubud, Kabupaten Gianyar. Antusias mereka sangat baik terhadap video tutorial tersebut karena dapat dimanfaatkan untuk menambah ilmu dalam bidang kerajinan kreatif yang dapat nantinya membantu ekonomi keluarga yang menurun di masa pandemi COVID-19 saat sekarang ini. Minimal mereka bisa menyulap baju yang sudah tidak lagi terpakai menjadi baju yang baru untuk mengikuti tran mode anak muda dimasa sekarang ini.
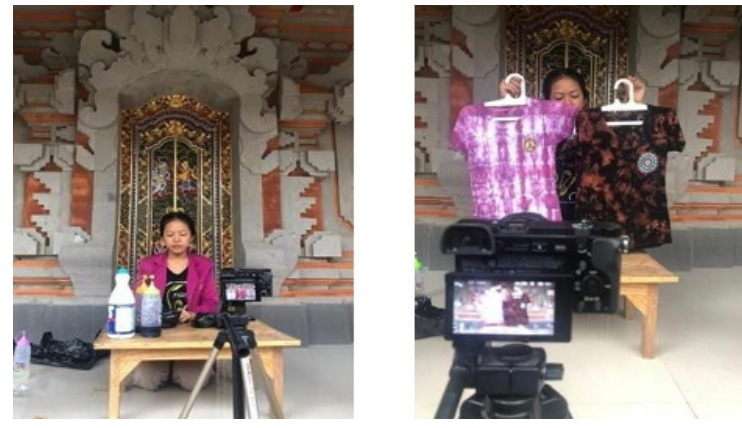

Foto 3. Pembuatan video tutorial tie dye
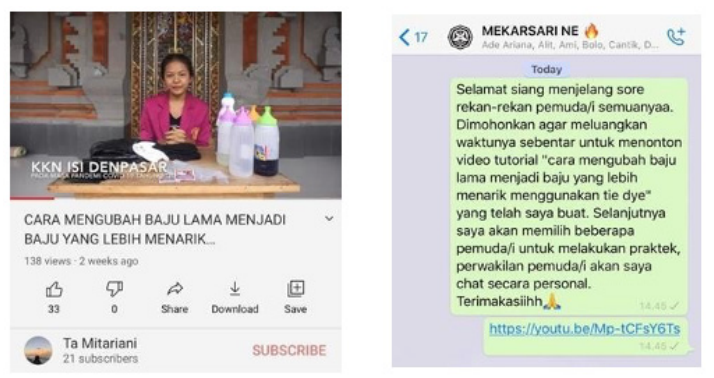

Foto 4. Video dibagikan di akun youtube pribadi penulis yang kemudian link video dibagikan ke grupwhatsapp Skaa Teruna-Teruni Padangtegal Mekarsari

\section{Kegiatan Minggu Ketiga Bulan Agustus Tahun 2020}

Pada minggu ketiga kegiatan mahasiswa dari jurusan desain mode di desa Padangtegal Mekarsari, Desa Ubud, Kabupaten Gianyar sudah ke tahap praktek langsung ke lapangan dengan tetap menjalankan protokol kesehatan. Kegiatan tersebut dimulai membagikan bahan-bahan untuk memperaktekan pembuatan masker kreatif dan membuat baju yang sudah tidak dipakai tapi masih layak dipakai menjadi baju baru dengan teknik tie dye kepada 10 orang muda-mudi yang merupakan anggota skaa teruna-teruni di Banjar Padangtegal Mekarsari, Desa Ubud Kabupaten Gianyar. Pada minggu ketiga ini mahasiswa melakukan pendampingan pembuatan baju tie dye terhadap 10 orang muda-mudi skaa teruna-teruni yang sudah dipilih sebelumnya. Selain itu, pada kesempatan tersebut mahasiswa juga memaparkan dan diskusi mengenai baju tie dye yang sedang tren an daya beli masyarakat terhadap baju tie dye. Pada saat itu juga dilakukan peyutingan dan hasil syuting yang berupa video yang kemudian diedit 

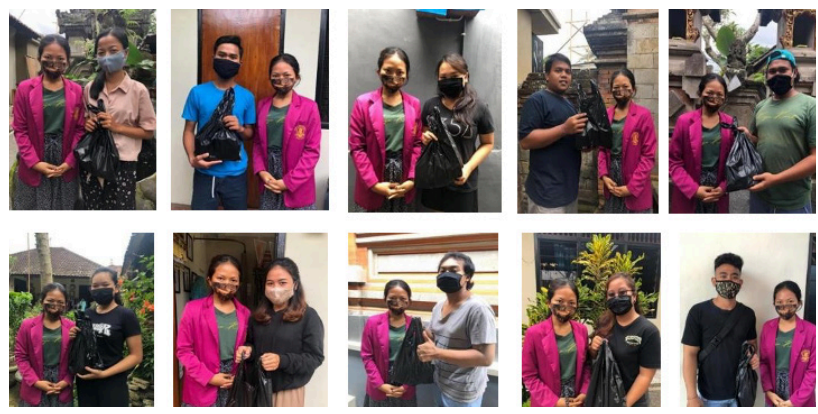

Foto 12. Membagikan bahan-bahan untuk membuat masker dan baju tie dye kepadaperwakilan pemuda-pemudi ST. Padangtegal Mekarsari

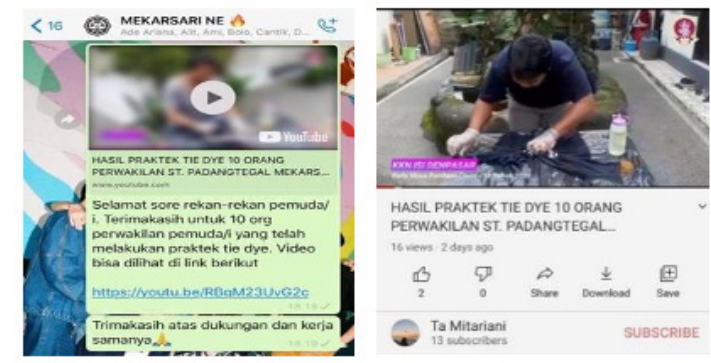

Foto 16. Video peraktek membuat baju dengan teknik tie dye dibagikanke media sosial seperti youtube dan whatsapp

sebelum diserahkan ke pihak Banjar Padangtegal Mekarsari,

Desa Ubud, Kabupaten Gianyar. Setelah editing usai, video diserahkan pada pihak desa disertai dengan presentasi dan serah terima. Berikut foto dokumentasi kegiatan tersebut.tersebut.

\section{Kegiatan Minggu Keempat Bulan Agustus Tahun 2020}

Kegiatan minggu keempat dilaksanakan pemaparan dan diskusi mengenai masker yang sedang tren di pasaran dan daya beli masyarakat terhadap masker kreatif. Tujuan dilakukan pemaparan dan diskusi tersebut agar warga yang diwakili oleh 10 orang muda-mudi mengetahui peluang bisnis untuk masker kreatif yang akan dibuat. Kemudian dilakukan pendampingan dalam praktek pembuatan masker kreatif dengan tetap menjalankan protokol kesehatan. Sebelum dimulai praktek pembuatan masker kreatif, mahasiswa memberi pemaparan dan diskusi kepada skaa Teruna-teruni dalam hal pentingnya penggunaan masker dan daya beli masyarakat terhadap masker kreatif di pasaran. Tujuan pemaparan dan diskusi tersebut agar warga yang diwakili oleh 10 orang muda-mudi mengetahui peluang bisnis untuk masker kreatif yang akan

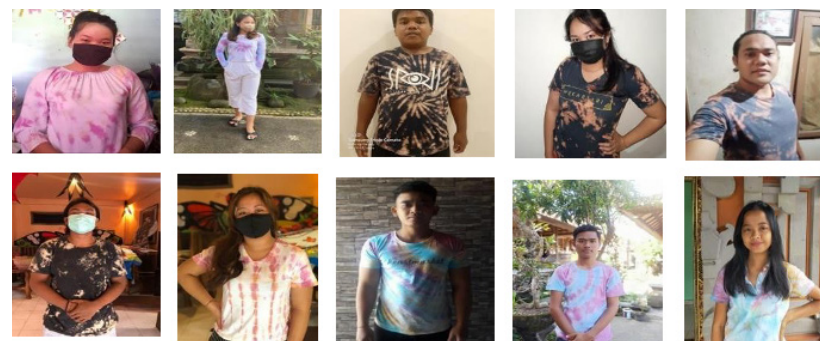

Foto 13. Hasil jadi tie dye perwakilan pemuda-pemudi ST. Padangtegal Mekarsari
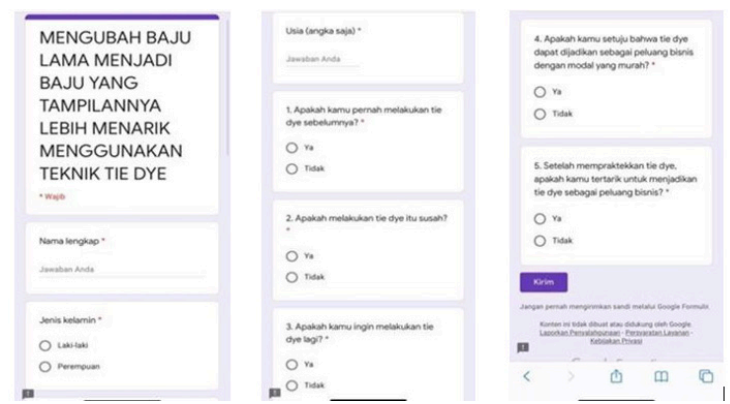

Foto 14. Menanyakan tanggapan kepada 10 orang perwakilan Skaa Teruna-Teruni Padangtegal Mekarsariyang melakukan praktek tie dye melalui Google Formulir.

dibuat. Pada saat itu juga dilakukan peyutingan dan hasil syuting yang berupa video yang kemudian diedit sebelum diserahkan ke pihak Banjar Padangtegal Mekarsari, Desa Ubud, Kabupaten Gianyar. Setelah editing usai, video diserahkan pada pihak desa disertai dengan presentasi dan serah terima. Berikut foto dokumentasi kegiatan tersebut.

Dari pelaksanaan program kerja yang dilaksanakan selama sebulan. Proses penyampaian informasi untuk edukasitelah dilaksanakan denganbaikmenggunakan bantuan teknologi media rekam dan internet. Nampakdalam pelaksanaan program tersebut telah ada sinergi yang baik dengan pihak desa, khususnya dalam memberikan sumbangsih ilmu yang berperan untuk membantu mengembangkan ekonomi kreatif dikalangan muda-mudi skaa teruna-teruni maupun masyarakat di Banjar Padangtegal Mekarsari, Desa Ubud, Kabupaten Gianyar. Video tutorial mengenai cara-cara pembuatan baju tie dye dan masker kreatif yang dihasilkan mahasiswa Mitariani diunggah di YouTube, sehingga dapat memberikan edukasi yang lebih luas di kalangan pengguna YouTube nantinya. Sehubungan dengan respon masyarakat, program kerja yang dilaksanakan dapatdinilai positif dan direspon baik oleh masyarakat, khususnya masyarakat Banjar Padangtegal Mekarsari, Desa 


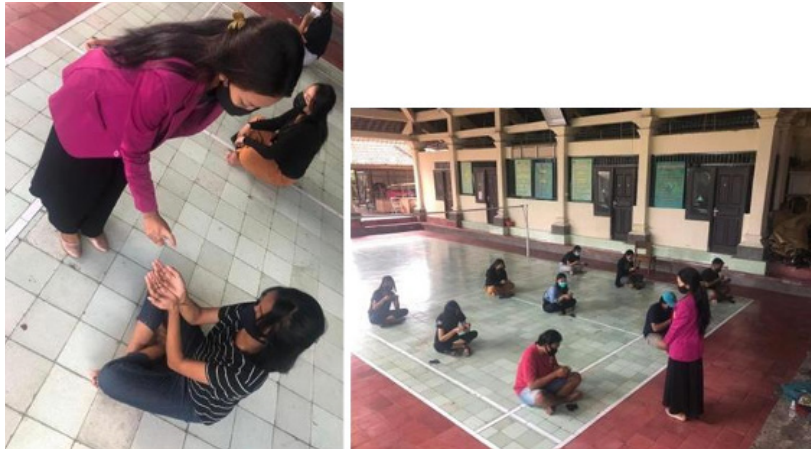

Foto 18. Praktek membuat masker bersama perwakilan pemuda-pemudi
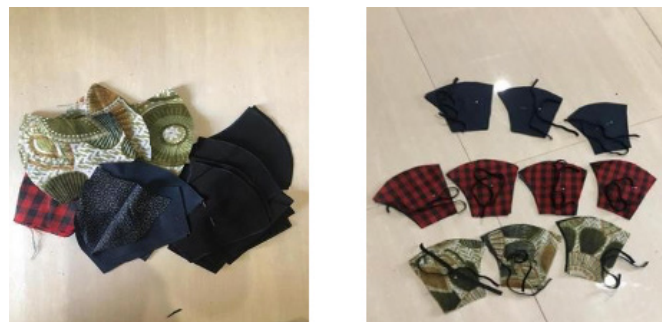

Foto 17. Bahan, alat dan hasil dari pendampingan yang berupa masker kreatif
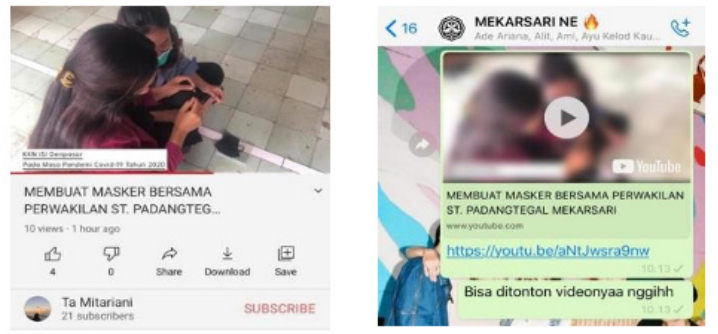

Foto 20. Membagikan video hasil praktek ke media sosial seperti youtube danwhatsapp

Ubud, Kabupaten Gianyar. Hal ini dibuktikan dengan antusias dari foto dokumentasi keterlibatan masyarakatdalam program kerja tersebut.

\section{SIMPULAN}

Program edukasi yang dilaksanakan pasca pandemi COVID-19, melalui KKN yang diselenggarakan ISI Denpasar berjalan dengan sangat baik. Edukasi yang diberikan cukup terperinci dan detail tentang peluang peningkatan ekonomi kreatif pasca pandemi, hingga kesadaran akan protokol kesehatan dan menumbuhkan kreativitas desain khususnya pada warga Banjar Padangtegal Mekarsari, Desa Ubud, Kabupaten Gianyar dalam menghadapi penurunan ekonomi di masa pandemi COVID-19. Program edukasi yang dilaksanakan menggunakan teknologi media rekam dan internet melalui pembuatan video tutorial yang diunggah di YouTube. Hal ini juga mampu memberikan nilai lebih, karena video edukasi yang diunggah dapat dilihat secaraluas. Respon yang diberikan masyarakat pun cukup antusias, melihat dari banyaknya warga Banjar Padangtegal Mekarsari yang turut berpartisipasi dalam program edukasi tersebut.

\section{DAFTAR RUJUKAN}

Muleong dan Laxy J. 2000. Metodologi Penelitian Kualitatif. Bandung: Rosadakarya. . 2005.

Metodologi Penelitian Kualitatif. Bandung: Remaja Rosda Karya.

Nusabali. (2020, Juli 5). Positif COVID-19 di Bangli Kembali Melonjak : Puluhan Wartawan di Rapid Test, Hasilnya Non Reaktif. Dipetik Agustus 18, 2020, dari https://www.nusabali.com:https://www. nusabali.com/berita/76769/positif-COVID-19-dibangli-kembali-melonjak

Sukmadinata dan Nana Syaodih. 2001. Metode Penelitian Pendidikan. Bandung: Rosdakarya. Sugiyono, S. (2010). Metode Penelitian Kuantitatif Kualitatif dan R\&D. Bandung: ALFABETA.

Ringtimesbali. (2020, Juli 13). Pasca Pandemi, Jumlah Orang Ekonomi Mapan di Gianyar Hanya 13.600 KK. Dipetik Agustus 18, 2020, dari https://ringtimesbali.pikiran-rakyat.com: https:// ringtimesbali.pikiran-rakyat.com/bali-news/pr28595327/pasca-pandemi-jumlah- orang-ekonomimapan-di-gianyar-hanya-1360o-kk 